\title{
ELISA 法による茶葉中のクロロタロニルの残留分析
}

\author{
畠 山えり子*，梶田弘子，菅原 隆 志，高 橋 悟 \\ 岩手県環境保健研究センター
}

(平成 20 年 2 月 4 日受付, 平成 20 年 7 月 17 日受理)

\section{Determination of chlorothalonil residues in raw tea and green tea leaves by an enzyme-linked immunosorbent assay}

\author{
Eriko Hatakeyama*, Hiroko Kajita, Takashi Sugawara, and Satoru Takahashi \\ Research Institute for Environmental Sciences and Public Health of Iwate Prefecture, \\ 1-36-1 Iiokashinden, Morioka 020-0852, Japan
}

\begin{abstract}
A simple, rapid method to determine residues of chlorothalonil in green tea leaves was developed using a commercial chlorothalonil kit based on ELISA. Chlorothalonil in green tea leaves was measured using the chlorothalonil kit after being extracted by methanol or boiling in water and diluted with $10 \%$ methanol. Because the extracts of green tea leaves caused significant interference in the assay, a refinement method was examined. One $\mathrm{ml}$ of the extract from green tea leaves boiled in water or extracted with methanol was added to Oasis HLB $(60 \mathrm{mg}$ ) and purified with $2 \mathrm{ml}$ of $80 \%$ methanol. After that, chlorothalonil on the HLB was extracted with $2 \mathrm{ml}$ of $100 \%$ methanol. It was suggested from the experiment that the component that was removed by column refinement was catechin, being the cause of interference with the chlorothalonil kit. As the results, average recoveries from the chlorothalonil-spiked green tea leaves were $86-113 \%$, and the coefficients of variation were below $10 \%$ in most cases. The coefficient of correlation between the ELISA and GC/MS methods was 0.99. Analysis equivalent to GC became possible using ELISA, and we revealed that catechin is the main factor interfering with ELISA analysis, and established a refining process. It was confirmed that the methanol treatment method for HLB was useful for the rapid analysis of chlorothalonil residues in green tea leaves. C Pesticide Science Society of Japan
\end{abstract}

Keywords: ELISA kit, chlorothalonil, green tea, matrix interference, catechin.

1. 緒

$\overline{\overline{\bar{⿳}}}$

近年，茶葉はその有効成分による機能性が注目され，飲 用のみならず食べるお茶としても重用されている。一方， 消費者の食品中の残留農薬への関心は高く, 茶においても 高濃度に残留しているのではとの懸念が指摘されており, 茶に残留する農薬の濃度レベルの把握が課題となっている. 分析法については, 厚生労働省からの通知法 ${ }^{1)}$ において茶

* 干 020-0852 盛岡市飯岡新田 1-36-1

E-mail:eri-hatake@pref.iwate.jp

(C) Pesticide Science Society of Japan
を抹茶と抹茶以外に分けた分析法が示されており，抹茶以 外の茶ではほとんどの農薬が熱湯抽出法による個別分析法 となっている. しかしながら, この方法による場合, 茶に 大量に含まれるカテキン類やクロロフィル等の夾雑物質を 除去するための煩雑な精製操作が必要となり, 検査に多大 な労力と時間を要している.

有機塩素系殺菌剤クロロタロニルは茶の栽培において炭 そ病予防のために用いられ，摘採 10 日前までの使用が認め られている. 本剤は水に溶けにくいため雨による流出も少 なく, また, 酸, アルカリ, 熱, 紫外線にも安定で農産物 への残留性が高いことから, 農産物中の残留農薬検査での 
検出頻度が高い農薬でもある。茶のクロロタロニルの残留 基準は，食品衛生法の規格基準によって規定され，抹茶以 外の茶では熱湯抽出法により検查する方法となっている. しかし，この方法による場合，水に溶けにくい農薬は浸出 され難い2）ことが指摘されており，茶葉の残留実態を把握 するためには，溶媒抽出法による方法についても調べる必 要があると考えられる. 本研究では, 機器分析法と較べて 前処理操作をほとんど必要せず，迅速・簡便かつ廉価な測 定法として注目されている ELISA 法について，市販のクロ ロタロニルキットを用い，溶媒抽出法扔よび熱湯抽出法の $2 つ の$ 抽出法を用いた測定法について検討を行った。

\section{2. 実 験 方 法}

2.1. 試料

原料茶葉（生茶葉）および市販の緑茶（緑茶）を用いた。

\section{2. 試薬類}

有機溶媒等: 有機溶媒は関東化学製の残留農薬分析用, 水はミリポア製のミリ $\mathrm{Q}$ 水，その他の試薬は関東化学製の 特級を用いた。

農薬標準品：関東化学製の残留農薬試験用農薬標準品を 用い,メタノール（ELISA 法）または n-へキサン（GC/MS 法）に溶解して $100 \mu \mathrm{g} / \mathrm{ml}$ 標準原液とし，さらに $10 \%$ メ夕 ノール溶液（ELISA 法），n-ヘキサン（GC/MS 法）で適宜 希釈した.

カテキン類標準品：和光純薬製の生化学用カテキン混合 物（緑茶由来，含有率 $85 \%$ 以上）をメ夕ノールに溶解し $1000 \mu \mathrm{g} / \mathrm{ml}$ 標準原液とし，50\%メタノールで適宜希釈した。

固相：Waters 社製のジビニルベンゼン $N$-ビニルピロリド ン共重合体ミニカラム（Oasis HLB, $60 \mathrm{mg}$ ）は，あらかじめ メタノールおよび $80 \%$ メタノール各 $1 \mathrm{ml}$ でコンデショニン グした後使用した。

\subsection{ELISA キット}

堀場製作所製のクロロタロニルキット（スマートアッセ イシリーズ）を用いた。

\section{4. 装置および測定条件}

\subsubsection{ELISA 法}

吸光光度計：堀場製作所製 Smart Reader MPR-01，遠心 分離機：トミー製 LX-140を用いた。なお，ELISA 法の測 定条件は，キットに示された方法に従った。

\subsubsection{GC/MS 法}

装置：GC Agilent 製 HP6890, MS Agilent 製 HP5973 inert, 分析用カラム Agilent DB-XLB（内径 $0.25 \mathrm{~mm}$, 長さ $30 \mathrm{~m}$, 膜厚 $0.10 \mu \mathrm{m}$ ）を用いた.

測定条件 : カラム温度 $80^{\circ} \mathrm{C}(1 \mathrm{~min})-\left(30^{\circ} \mathrm{C} / \mathrm{min}\right)-180^{\circ} \mathrm{C}-$ $\left(5^{\circ} \mathrm{C} / \mathrm{min}\right)-250^{\circ} \mathrm{C}-\left(10^{\circ} \mathrm{C} / \mathrm{min}\right)-310^{\circ} \mathrm{C}(5.5 \mathrm{~min})$ の昇温とし て, 注入口温度は $230^{\circ} \mathrm{C}$, インターフェース温度は $290^{\circ} \mathrm{C}$, キャリアガス（ヘリウム）, 注入方法はスプリットレス, 注 入量は $2 \mu \mathrm{l}$, 測定モードは SIM（m/z 266）で行った。

\subsection{3. 茶カテキン類の定量}

装置：LC Agilent 製 1100, 分析用カラム SHISEIDO 製 SUPERIOREX ODS（内径 $4.6 \mathrm{~mm}$, 長さ $150 \mathrm{~mm}$, 粒子径 $5 \mu \mathrm{m}$ ）を用いた。

測定条件：移動相メ夕ノール - 水 $(10 / 90) \rightarrow 30 \mathrm{~min}$ (50/50), カラム温度 $40^{\circ} \mathrm{C}$, 流量 $1 \mathrm{ml} / \mathrm{min}$, 注入量 $10 \mu \mathrm{l}$, 検出器 UV230 nm を用いた.

\subsection{ELISA 法による試験溶液の調製}

\subsection{1. 溶媒抽出法}

生茶葉 $50 \mathrm{~g}$ に水 $45 \mathrm{ml}$ および $50 \%$ リン酸 $5 \mathrm{ml}$ 加え，フー ドプロセッサーを用いて細切均一化した後, その $2.0 \mathrm{~g}$ (茶 葉として $1.0 \mathrm{~g}$ 相当）をポリプロピレン遠心管に採取した. これに，水 $1 \mathrm{ml}$ 抢よびメタノール $10 \mathrm{ml}$ 加え， 30 分間振と う抽出した後， $3,000 \mathrm{rpm}$ で 10 分間遠心分離した。上清を $10 \mathrm{ml}$ 容メスフラスコに移し，水を加えて $10 \mathrm{ml}$ に定容した 液 $1 \mathrm{ml}$ を，あらかじめメ夕ノール $1 \mathrm{ml}, 80 \%$ メタノール $1 \mathrm{ml}$ でコンデショニングした Oasis HLB ミニカラム $(60 \mathrm{mg})$ に負荷した。 その後， $80 \%$ メタノール $2 \mathrm{ml}$ でカラムを洗浄 し，洗浄液等を捨てたのち，メ夕ノール $2 \mathrm{ml}$ で溶出した。 この溶出液にメタノール $0.5 \mathrm{ml}$ および水を加えて $25 \mathrm{ml}$ に定 容した液を ELISA 用試験溶液とした。なお，緑茶は粉砕し た試料 $1.0 \mathrm{~g}$ に水 $2 \mathrm{ml} ， 50 \%$ リン酸 $0.1 \mathrm{ml}$ 抢よびメタノール $10 \mathrm{ml}$ 加えて 15 分間放置したのち，生茶葉と同様に操作し て試験溶液を調製した。

\subsection{2. 熱湯抽出法}

緑茶 $1.0 \mathrm{~g}$ に沸騰水 $50 \mathrm{ml}$ 加えて 5 分間放置した後，吸引 万過し，冷却後メタノール $5 \mathrm{ml}, 50 \%$ リン酸 $0.1 \mathrm{ml}$ 加えて $50 \mathrm{ml}$ に定容した。その液 $1 \mathrm{ml}$ を，あらかじめメ夕ノール $1 \mathrm{ml}, 10 \%$ メタノール $1 \mathrm{ml}$ でコンデショニングした Oasis HLB ミニカラム $(60 \mathrm{mg})$ に負荷した。 その後, $80 \%$ メ夕 ノール $2 \mathrm{ml}$ でカラムを洗浄し, 洗浄液等を捨てたのち, メ タノール $2 \mathrm{ml}$ で溶出し, 水を加えて $20 \mathrm{ml}$ に定容した液を ELISA 用試験溶液とした。

\subsection{GC/MS 法による試験溶液の調製}

\subsection{1. 溶媒抽出法}

溶媒抽出法は通知法 ${ }^{1)}$ に示された抹茶の分析法により調 製した。

2.6.2. 熱湯抽出法

熱湯抽出法は通知法 ${ }^{1)}$ に示された抹茶以外の茶の分析法 により調製した。 
2.7. クロロタロニルキットにおける茶成分の影響調査

あらかじめ GC/MS 法によりクロロタロニルが残留してい ないことを確認した生茶葉扰よび緑茶を用いて調製したメ タノール抽出液を適宜 $10 \%$ メタノールで希釈して ELISA 用 試験溶液とした。はじめに，先に調製した茶のメタノール 抽出希釈液にクロロタロニル標準品を添加する方法で作製 した添加検量線と $10 \%$ メタノール液を用いて作成した標準 検量線との乘離状沉を比較した。次に，茶成分の影響によ るクロロタロニル擬陽性反応を調べるため，クロロタロニ ル無添加の吸光度からもとめた $\mathrm{B} / \mathrm{B}_{0} \%$ 值（各試験溶液の吸 光度／陰性コントロールの吸光度 $\times 100 ）$ が検出下限付近 の $80 \%$ を超えない希釈率を求めるとともに, ELISA 法によ る測定に扔いてマトリックスの影響を最も受けやすい低濃 度域 $(0.15 \mathrm{ng} / \mathrm{g})$ での測定を行い，回収率を比較した。

\section{8. 妨害除去方法の検討}

クロロタロニルキットでの妨害物質を取り除く手段とし て Oasis HLB（60 mg）による前処理方法について検討した. はじめに, クロロタロニル標準溶液のメタノール濃度を 10 100\%に変化させて, Oasis HLB ミニカラムでのクロロ タロニルの保持抒よび溶出試験を行った。次に，生茶葉の 抽出液 $1 \mathrm{ml}$ を Oasis HLB ミニカラムに負荷後, 洗浄液のメ タノール濃度を各々 10 $70 \%$ の条件で洗浄したのち, メ夕 ノールで溶出し，希釈調製した各試験溶液（250 倍希釈相 当）にクロロタロニルを $0.15 \mathrm{ng} / \mathrm{g}$ 相当添加して測定する方 法で，妨害物質の除去効果を確認した。

\section{9. 溶出液中のカテキン類の定量}

Oasis HLB ミニカラム精製に扔いて，洗浄液のメタノー ル濃度によって, 溶出液中のカテキン類の濃度が, どの程 度減少しているか試験を行った。カテキン類の定量は高速 液体クロマトグラフィー（UV 法）を用い，緑茶中の主要 カテキン類であるエピカテキン，エピカテキンガレート，工 ピガロカテキンおよびエピガロカテキンガレートについて, カテキン混合物（緑茶由来）標準品の面積比から求めた.

\subsection{0. カテキン混合物標準品による妨害の確認}

カテキン類が妨害の要因であることを確認するため, 次 の試験を行った。すなわち， $0.15 \mathrm{ng} / \mathrm{g}$ クロロタロニル含有 $10 \%$ メタール溶液に緑茶由来カテキン混合物（標準品） を 10 2000 $\mu \mathrm{g} / \mathrm{g}$ の濃度範囲で添加して測定し，カテキン混 合物濃度と吸光度低下の関係を調べた。

\subsection{1. 添加回収試験}

生茶葉では溶媒抽出法, 緑茶では熱湯抽出法により, 確 立した前処理条件に基づき添加回収試験を行った。添加濃 度はそれぞれの方法における検出下限值濃度および基準值
の約 $1 / 10$ 濃度とし，クロロタロニル標準品の添加時期は, 溶媒抽出法に扔いては抽出前，熱湯抽出法においては抽出 後とした。

\subsection{ELISA 法と GC/MS 法との相関性試験}

確立した ELISA 測定条件を用い，既知濃度を添加する方 法で ELISA 法と GC/MS 法の比較試験を行った。なお，抽 出法は生茶葉では溶媒抽出法, 緑茶では熱湯抽出法の条件 を用いた。添加濃度は生茶葉が $0.0375 \mu \mathrm{g} / \mathrm{g}$ から $1.5 \mu \mathrm{g} / \mathrm{g}$, 緑茶が $0.15 \mu \mathrm{g} / \mathrm{g}$ から $1.5 \mu \mathrm{g} / \mathrm{g}$ の範囲とした.

\subsection{3. 実態調査}

市販の緑茶 10 検体を対象に熱湯抽出法により, ELISA 法および GC/MS 法によるクロロタロニルの残留実態調査を 行った。

\section{3. 結果および考察}

\section{1. 茶成分によるクロロタロニルキットでの妨害}

通常，ELISA 法による農作物中の残留農薬測定において は，抽出溶媒はメ夕ノールを用い，抽出液に水を加えメ夕 ノール濃度を $10 \%$ に調整した希釈液を測定に供する。しか し，作物によっては測定での妨害が指摘 $3-9)$ されており，作 物成分による測定への影響の確認が必要である。茶葉のメ タノール抽出液を 250 倍に希釈して作成した添加検量線と 10\%メタノール液を用いて作成した標準検量線を Fig. 1 に 示した。添加検量線の吸光度は低濃度域で最も大きく抑制 されており，検量線の傾きはほとんど 0 に近い值を示した。 この結果, 茶の抽出液が混在するとクロロタロニルの抗体 との反応性が変化することが明らかとなり，茶に由来する 成分の影響が考えられた。このような夾雑成分による

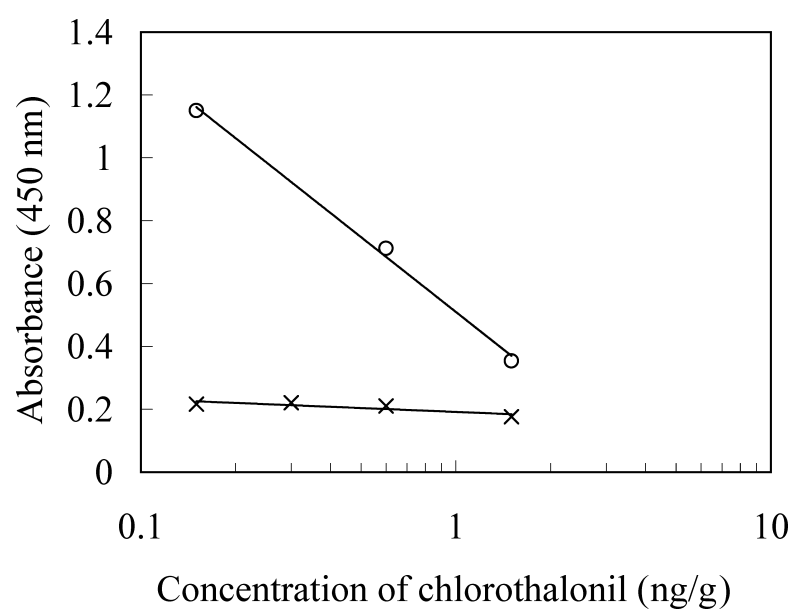

Fig. 1. Influence of green tea leaf matrix on the standard curve for chlorothalonil. ELISA standard curves of chlorothalonil in $10 \%$ methanol in the absence $(\bigcirc)$, and in the presence $(X)$ of methanol extract of raw tea leaves are shown. The methanol extract was prepared by diluting the original extract with $10 \%$ methanol by 250 -fold, into which specified amount of chlorothalonil was add. 
Table 1. Effect of dilution factors of methanol extracts from the leaves of raw tea and grean tea on $\mathrm{B} / \mathrm{B}_{0}$ values $(\%)$ in the analysis using ELISA kit for chlorothalonil

\begin{tabular}{rcc}
\hline & \multicolumn{2}{c}{$\mathrm{B} / \mathrm{B}_{0}(\%)^{b)}$} \\
\hline Dilution factor $^{a)}$ & Raw tea leaves & Green tea leaves \\
\cline { 2 - 3 } 250 -fold & 16.2 & 6.7 \\
500 -fold & 24.8 & 9.1 \\
1,000-fold & 39.6 & 16.4 \\
2,000-fold & 65.9 & 20.5 \\
3,000-fold & 94.6 & 26.8 \\
5,000 -fold & $-c)$ & 32 \\
\hline
\end{tabular}

${ }^{a)}$ Sample solution was diluted with $10 \%$ methanol. ${ }^{\text {b) }} \mathrm{B} / \mathrm{B}_{0}$ $(\%)=\mathrm{B} / \mathrm{B}_{0} \times 100 . \mathrm{B}_{0}$ : Absorbance of $10 \%$ methanol. B: Absorbance of diluted methanol extract of raw tea and green tea leaves with $10 \%$ methanol. ${ }^{c}$ Not mesured.

ELISA への影響は, 抽出液をさらに希釈することで反応性 の改善が期待できると考えられたため, 希釈による方法で 影響を回避することを試みた。ブランク值の吸光度から $\mathrm{B} / \mathrm{B}_{0} \%$ 值（各試験溶液の吸光度／陰性コントロールの吸光 度 $\times 100$ ）を求めた結果を Table 1 に示した。希釈率を上げ ることで $\mathrm{B} / \mathrm{B}_{0} \%$ 值は徐々に改善される傾向を示したが，生 茶葉では 2000 倍, 緑茶では 5000 倍に希釈しても, ブラン ク值が検出下限值を超える偽陽性反応を生じることがわ かった。 また，最も影響を受けやすい低濃度域 $(0.15 \mathrm{ng} / \mathrm{g})$ での測定值も過大な值を示した（Table 2).

\section{2. 茶成分による ELISA 法での妨害とその除去方法の 検討}

先の試験の結果，希釈のみの操作で妨害を除去すること は困難であったことから，ミニカラムを用いた精製法につ

Table 2. Effect of dilution factors of methanol extracts from the leaves of raw tea and grean tea on spike recovery in the analysis using ELISA kit for chlorothalonil

\begin{tabular}{rcc}
\hline \multirow{2}{*}{ Dilution factor } & \multicolumn{2}{c}{ Spike recovery $(\%)^{a)}$} \\
\cline { 2 - 3 } & Raw tea leaves & Green tea leaves \\
\hline 250 -fold & 1360 & $-{ }^{b)}$ \\
1,000 -fold & 850 & 1400 \\
2,000 -fold & 440 & 900 \\
5,000 -fold & 180 & 610
\end{tabular}

a) Chlorthalonil $(0.15 \mathrm{ppb})$ was added to the methanol extract of the raw tea and green tea leaves diluted 250-, 1,000-, 2,000-, 5,000 -fold by $10 \%$ methanol, followed by chlorothalonil kit measurement. ${ }^{b)}$ Outside measurement range.
Table 3. Improvement of spike recovery by increasing the methanol concentration in the washing liquid for the pretreatment of methanol extracts from raw tea leaves with Oasis HLB column

\begin{tabular}{lc}
\hline Methanol concentration & Spike recovery $(\%)^{a)}$ \\
\hline No processing & \\
$10 \% \mathrm{MeOH}$ & 1,359 \\
$60 \% \mathrm{MeOH}$ & 818 \\
$70 \% \mathrm{MeOH}$ & 247 \\
\hline
\end{tabular}

a) methanol extract from tea leaves was treated with Oasis HLB column, and chlorothalonil $(0.15 \mathrm{ppb})$ was added to the eluate to be quantified using the ELISA kit. ${ }^{b)}$ Methanol extraction liquid of raw green tea leaves was diluted 250 -fold using $10 \%$ methanol.

いて検討した. ミニカラムはクロロタロニルのオクタノー ル /水分配係数が 4.38 と低極性であることに着目して, 幅 広い極性の物質を保持しつつ洗浄により比較的水溶性の高 い物質が除去できるジビニルベンゼン $N$-ビニルピロリドン 共重合体ミニカラム（Oasis HLB, $60 \mathrm{mg}$ ) を用いた. はじめ に，クロロタロニル標準溶液のメタノール濃度を $10 \sim 100 \%$ に変化させて, Oasis HLB ミニカラムによるクロロタロニ ルの保持および溶出試験を行った. その結果, クロロタロ ニルはメタノール濃度 90\% までは Oasis HLB ミニカラムに 保持され，100\%メタノールで溶出することがわかった. 次 に, 生茶葉の抽出液（メタノール濃度は約 $80 \%$ ） $1 \mathrm{ml}$ を Oasis HLB ミニカラムに負荷後, 洗浄液のメ夕ノール濃度 を各々 $10 \sim 70 \%$ の条件で洗浄したのち, メ夕ノールで溶出 し，希釈調製した試験溶液（250 倍希釈相当）にそれぞれ クロロタロニルを $0.15 \mathrm{ng} / \mathrm{g}$ 相当添加して測定した結果を Table 3 に示した。添加量に対する実測值の割合は洗浄液の メ夕ノール濃度依存的に改善され，70\%メ夕ノールで洗浄 した場合，ほぼ影響を回避できることが確認できた。

\section{3. 洗浄液のメタノール濃度によるカテキン類の除去}

洗浄水のメタノール濃度を変えて調製した ELISA 用試験 溶液中のカテキン類を定量した結果を Table 4 に示した. カ テキン類の除去率（洗浄しない場合 $0 \%$ ）は洗浄水のメ夕 ノール濃度依存的に高まり，70\%メタノールでは除去率 93\% とほとんどのカテキン類を除くことができた.

\section{4. カテキン混合物標準品による妨害の確認}

$0.15 \mathrm{ng} / \mathrm{g}$ クロロタロニル含有 $10 \%$ メタノール溶液に緑茶 由来カテキン混合物（標準品）を 10 2000 $\mu \mathrm{g} / \mathrm{g}$ の濃度範囲 で添加して測定した結果を Fig. 2 に示した. 試験溶液の吸 光度はカテキン混合物濃度に依存して指数関数的に減少し, 
Table 4. Effect of methanol concentration in the washing liquid in Oasis column pretreatment on the removal of catechins in the extract of grean tea leaves

\begin{tabular}{|c|c|c|c|c|c|c|}
\hline \multirow{2}{*}{$\begin{array}{c}\text { Methanol } \\
\text { concentration }\end{array}$} & \multicolumn{5}{|c|}{ Amount of catechins in test solution for ELISA $(\mu \mathrm{g} / \mathrm{g})$} & \multirow{2}{*}{$\begin{array}{c}\text { Catechin removal } \\
\text { factor }(\%)^{e)}\end{array}$} \\
\hline & $\mathrm{EGC}^{a)}$ & $\mathrm{EGCg}^{b)}$ & $\mathrm{EC}^{c)}$ & $\operatorname{Ecg}^{d)}$ & Total & \\
\hline No processing $f$ ) & 25 & 384 & 36 & 82 & 528 & 0 \\
\hline $10 \% \mathrm{MeOH}$ & 3 & 96 & 4 & 24 & 127 & 76 \\
\hline $60 \% \mathrm{MeOH}$ & 0 & 70 & 1 & 22 & 94 & 82 \\
\hline $70 \% \mathrm{MeOH}$ & 0 & 26 & 0 & 11 & 37 & 93 \\
\hline
\end{tabular}

a) epigallocatechin. ${ }^{b)}$ epigallocatechin gallate. ${ }^{c)}$ epicatechin. ${ }^{d)}$ epicatechin gallate. ${ }^{e)}$ (Total amount of catechins with no processing-Total amount of catechins by each methanol concentration)/(Total amount of catechins with no pocessing) $\times 100 .{ }^{f)}$ no Oasis HLB treatment.

競合 ELISA に典型的な濃度反応曲線を示していた。このこ とは, カテキン類がクロロタロニルキットでの妨害の要因 であると示唆された．次に，カテキン類の存在と他の夾雑 物質の影響を調べるため, 生茶葉のメタノール抽出液を用 いて次の試験を行った。すなわち，Oasis HLB ミニカラム 精製によりカテキン類の影響を排除したのち，処理前と同 程度のカテキン混合物標準品を添加する方法でカテキン類 の影響を確認した。その結果, カテキン混合物標準品の添 加により吸光度の低下が見られ，その回収率は約 $600 \%$ で あった．生茶葉でのミニカラム精製をしない場合の回収率 が約 1300\% であったことから茶成分によるクロロタロニル キットでの妨害の要因としてはミニカラム精製により排除 されるカテキン類以外の物質も示唆された。

\section{5. 添加回収試験}

確立した前処理方法を用いて作成した生茶葉の添加検量 線の例を Fig. 3 に示した。標準検量線との乘離が改善され, 茶成分による測定への影響を回避できることがわかった。 なお，本処理法により妨害を完全に回避できる希釈倍率は，

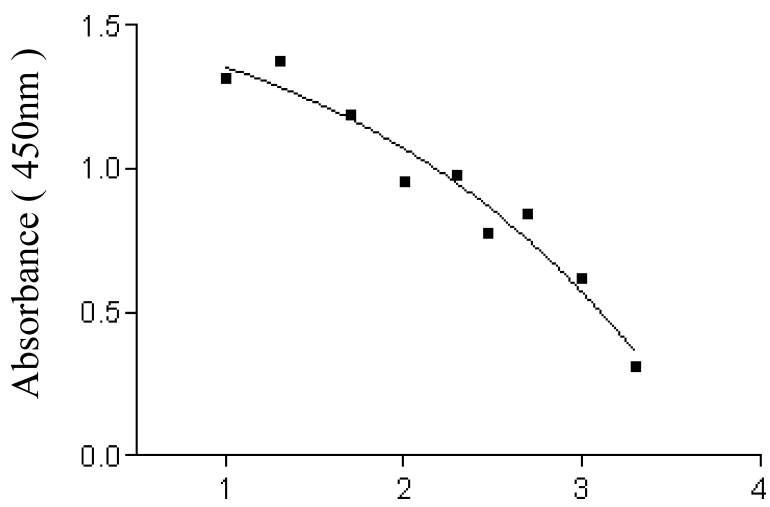

Concentration of catechin $(\log \mu \mathrm{g} / \mathrm{g})$

Fig. 2. Influence of the catechin concentration on the chlorothalonil kit.
生茶葉で 250 倍, 緑茶で 1000 倍であった. 次に, 生茶葉お よび緑茶を対象に確立した前処理条件に基づき, 既知濃度 添加する方法で添加回収試験を行った結果を Table 5 に示し た。各試料に対する平均回収率は $86 \%$ から $113 \%$ の範囲, 変動係数も打打む㸚 $10 \%$ 以内であり, 残留農薬検查におけ る精度管理指標（回収率が $70 \%$ から $120 \%$ の範囲, 変動係 数 $20 \%$ 以下）を満たしていた。本法を用いた場合のクロロ タロニルの検出下限は生茶葉で $0.04 \mu \mathrm{g} / \mathrm{g}$, 市販の緑茶で $0.15 \mu \mathrm{g} / \mathrm{g}$ であり, 茶の残留基準 $10 \mu \mathrm{g} / \mathrm{g}$ に対して十分な感 度で測定が可能であった。

\subsection{ELISA 法と GC/MS 法との相関性試験}

生茶葉を用いた溶媒抽出法による相関性試験のおよび緑 茶を用いた熱湯抽出法による相関性試験の結果を Fig. 4 に 示した。溶媒抽出法では相関係数 0.996 , 傾き 1.01 , 熱湯 抽出法では相関係数 0.989 , 傾き 1.19 といずれの抽出条件 においても，非常に高い相関関係が認められ，ELISA 法に

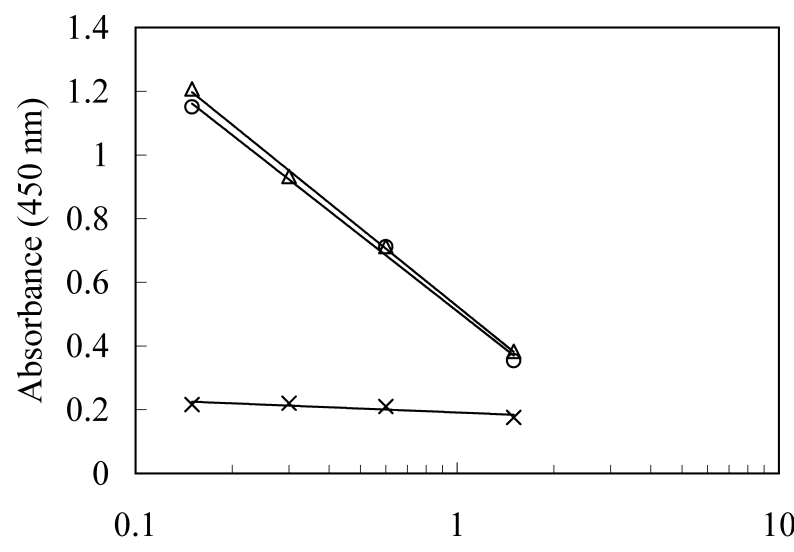

Concentration of chlorothalonil (ng/g)

Fig. 3. ELISA standard curves of chlorothalonil in methanol diluted in $10 \%$ methanol $(\bigcirc)$, raw green tea leaf methanol extract without purification $(\times)$, raw green tea leaf extract purified using HLB $(\triangle)$. 
Table 5. Recovery of chlorothalonil added to the leaves of raw tea and grean tea in the analysis using ELISA kit

\begin{tabular}{ccccc}
\hline Sample & Spike level $(\mu \mathrm{g} / \mathrm{g})$ & Etraction method & Recovery $(\%, \mathrm{n}=3)$ & CV $(\%)$ \\
\hline Raw tea leaves & 0.0375 & Solvent extraction & 86.0 & 8.1 \\
\multirow{2}{*}{ Green tea leaves } & 0.9 & & 93.3 & 8.7 \\
& 0.15 & Hot water extraction & 113.3 & 10.2 \\
& 0.9 & & 89.0 & 10.2 \\
& 1.5 & & 99.9 & 6.5 \\
\hline
\end{tabular}

おいても GC/MS 法と同等の測定が可能であることが確認で きた。

\section{7. 実態調査}

市販の緑茶 10 検体を対象に熱湯抽出法による ELISA 法 と GC/MS 法によるクロロタロニルの残留実態調査を行っ た。全ての検体において ELISA 法および GC/MS 法とも検 出下限值未満であった。なお， ELISA 法による検出下限は $0.15 \mu \mathrm{g} / \mathrm{g}, \mathrm{GC} / \mathrm{MS}$ 法による検出下限は $0.05 \mu \mathrm{g} / \mathrm{g}$ であった. また, ELISA 法の前処理時間は 10 検体でも 30 分程度と GC/MS 法の前処理時間 10 時間に比べて極めて迅速であっ た.

\section{要 約}

ELISA 法に基づく市販のクロロタロニルキットを用い, 茶葉中のクロロタロニル迅速分析法を検討した。クロロタ ロニルキットでは，茶の成分による妨害が顕著であったた め，精製方法について検討した結果，茶葉のメタノール抽

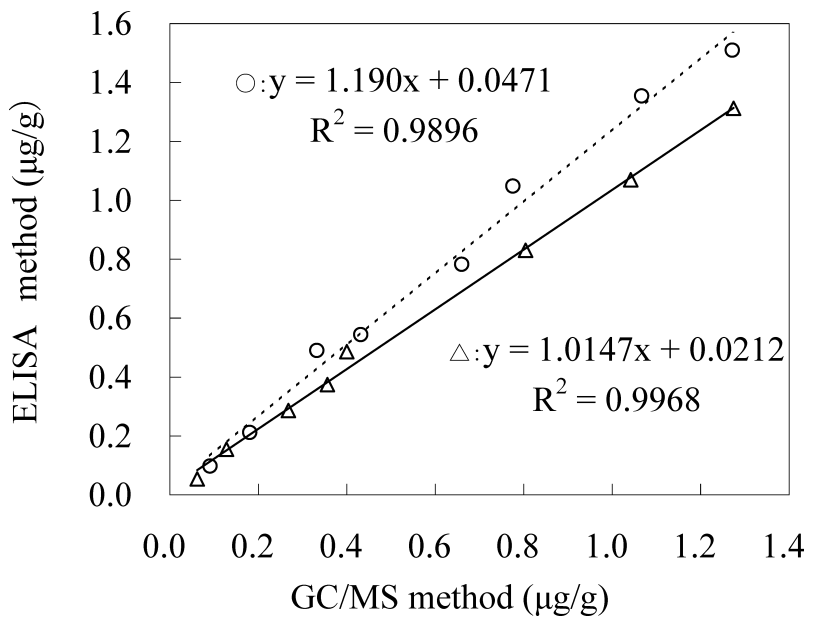

Fig. 4. Correlation between the estimated concentrations of chlorothalonil in the spiked green tea analyzed by the established ELISA method and the reference GC/MS method in solvent extraction $(\triangle)$ and hot water extraction $(\bigcirc)$.
出液あるいは熱湯抽出液 $1 \mathrm{ml}$ を Oasis HLB $(60 \mathrm{mg})$ ミニカ ラムに負荷し， $80 \%$ メタノル $2 \mathrm{ml}$ を用いて洗浄したのち メタノール $2 \mathrm{ml}$ で溶出する方法を確立した。本ミニカラム により除去した主要な成分はカテキン類で，クロロタロニ ルキットによる測定での妨害の原因物質であることが実験 から示唆された。本条件を用いて添加回収試験を行った結 果，平均回収率 86 113\%，変動係数打括むね $10 \%$ 以下て あった。 また，GC/MS 法との相関性試験においても，相関 係数 0.99 , 傾きもおおむね 1 に近い良好な結果が得られ， ELISA 法においても GC 法と同等の測定が可能になった. 本法を用いた場合の精製に要する時間は 10 検体で 30 分程 度と $\mathrm{GC} / \mathrm{MS}$ 法での前処理時間 10 時間に比べて極めて迅速 であった。これらの結果から，本法は，茶葉中のクロロ夕 ロニル残留迅速分析法として有用であると考えられる。

謝辞

本論文の作成にあたり，貴重なご意見をいただいた(侏)堀 場製作所三宅司郎博士に深謝いたします.

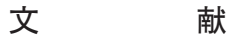

1）厚生労働省医薬品食品局食品安全部長通知第 012400 号 (平成 17 年 1 月 24 日付).

2) 永山敏廣, 真木俊夫, 観 公子, 飯田真美, 田村行弘, 二島太一郎：農薬誌 14, 39-45 (1989).

3) 津村ゆかり, 外海康秀, 中村優美子, 宮田昌弘, 鎌倉和 政, 橋端直樹, 岩田邦彦, 伊藤澄夫, 皆葉清美, 沖 賢 憲，児玉光男，伊藤誉志男：食衛誌 33, 458-466 (1992).

4) 三宅司郎，石井康雄：植物防疫 54, 148-152 (2000).

5) 平成 11 年度厚生科学研究: 食品中の残留農薬検査超迅速 化に関する研究報告書, 67-76 (2000).

6) E. Watanabe, H. Eun, K. Baba, T. Arao, Y. Ishii. S. Endo and M. Ueji: Anal. Chim. Acta 512, 45-51 (2004).

7) 畠山えり子, 梶田弘子, 菅原隆志, 小向隆志, 中野覀弓, 築地邦晃：岩手県環境保健研究センター年報 4, 90-94 (2004).

8) S. Wang, J. Zhang, Z. Yang, J. Wang and Y. Zhang: J. Agric. Food Chem. 53, 7377-7384 (2005).

9) 天野昭子，矢野秀治：農薬誌 31，425-430 (2006) 